\title{
APPLICATION OF VERMIFILTRATION FOR SUSTAINABLE MANAGEMENT OF SEPTAGE
}

\section{Nadejda Andreev ${ }^{1}$, Peter Matuku Mawioo², Elena Zubcov ${ }^{1}$, Nina Bagrin ${ }^{1}$, Anastasia Ivanova ${ }^{1}$, Antoaneta Ene ${ }^{3}$}

${ }^{1}$ Institute of Zoology, Chisinau, Republic of Moldova, email: nadia.andreev@gmail.com

${ }^{2}$ University of Eldoret, Eldoret, Kenya

${ }^{3}$ University Dunarea de Jos Galati, Romania

\begin{abstract}
The current article presents an innovative technical solution for sustainable management of septage, via a vermifiltration system, in the Republic of Moldova. A technical description of the main components of a demonstration model that was implemented at a household level is presented. The results from the model show an 98.85\% reduction of ammonia content, 49,21\% CODMn (an indicator of degradation of easily degradable organic substances) and $85,28 \%$ of CODCr (showing degradation of hardly degradable organic substances). Considering the fact that the concentration of ammonium in the effluent was considerable reduced, while that of nitrate nitrogen remained rather low, it was assumed that the activity of earthworms was rather limited, probable the microorganisms, interacting symbiotically and synergistically with earthworms not being well developed in the vermifilter bed. The study suggests that the vermifiltration technology can provide a sustainable wastewater management solution and its application can be promoted in certain settings such as schools and kindergartens in Moldova. However, good insulation should be considered to avoid the freezing problems during winter while the odor nuisance in the septic tank can be reduced by adding lactic acid bacteria can also be applied.
\end{abstract}

\section{Introduction}

A septic tank is a watertight chamber made of concrete, fiberglass, PVC or plastic, through which blackwater and greywater flows for primary treatment. Septic tanks are simple technologies, with low operation costs, long service life and limited land requirements, as they are usually built underground. Settling and anaerobic processes reduce solids and organics, but the treatment is only moderate. In the context of climate change, with intensification of droughts, reuse of wastewaters for irrigation as an alternative to drinking water is gaining significant importance. In the Republic of Moldova, septic tanks or infiltration pits are widely used in rural areas, however, they contribute to a high pollution of the groundwater sources. As such, the introduction of new technologies for the treatment of wastewater from the septic tanks to the level that it can be reused would be a good alternative to the current existing models.

One such technology is the vermifiltration or lumbrifiltration, which is the application of earthworms in wastewater treatment [1-2]. Vermifiltration is a new technology based on aerobic treatment of wastewater by earthworms. The use of vermifiltration systems is important for rural areas of Moldova, where flush toilet systems are commonly applied. These systems are usually connected to infiltration pits, often leading to pollution of groundwater, which serves as drinking water sources for a large portion of the population. In this study, a vermifitration unit was applied in the treatment of a septic tank effluent. The potential reuse of th treated wastewater was evaluated by WiSDOM association in collaboration with Ecotox association and Laboratory of Hydrobiology and Ecotoxicology, Institute of Zoology. A vermifiltration 
system usually consist of a biological reactor, containing a filtration media that filters the oranic material and an earthworm layer, which contributes to the reduction of pathogens and organic matter (fig. 1).

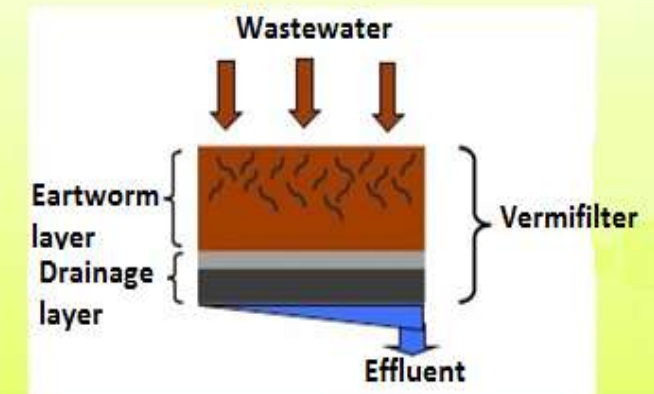

Figure 1. A schematic view of a vermifilter. Source: [3]

\section{Materials and methods}

The demonstration vermifiltration system was built with 4 main components including a septic tank with two compartments (1), an equalization tank (equalizer) (2), a distribution reservoir with associated distribution pipe system (3) and a vermifilter (4) (fig. 2). In the first chamber of the septic tank, settling of the solids as well as anaerobic digestion take place, which contribute to volume reduction. After this primary treatment, the liquid fraction of the wastewater is transported via an opening into the baffle wall to the second chamber, where additional sedimentation takes place. Excess liquid, relatively clear, is then drained through an outlet pipe into the equalization tank. This tank acts as a buffer to maintain a constant flow and prevent over peaking, which could force solids and fresh organic material to be pumped into the vermifilter. A submersible pump with a level sensor is installed in the equalizing tank. The level sensor measures the level of wastewater in the equalizing tank and triggers the pumping process, which pumps the wastewater into the distribution reservoir

The distribution reservoir is located above the vermifiler, thus the wastewater flows by gravity via a system of perforated pipes and is distributed further over the entire surface of the vermifiltre. In the vermifiltre the top layer is the substrate for earthworms (Eisenia foetida)- a layer of shredded paper, covered with a layer of soil mixed with organic waste, where the compost earthworms Eisenia foetida are placed. Beneath the earthworm substrate, a layer of biochar is placed, which absorbs pollutants that have not been decomposed by earthworms. Under the biochar layer there are also two layers of gravel of sizes 2-10 and 20-40 mm, which serve as filtration media. At the bottom of the vermifiltre there is a system of perforated pipes that directs the treated effluent to a drip irrigation system. In order to prevent freezing of the vermifilter during the cold period and to ensure that the earthworms are active, the vermifilter is covered with a polyethylene foil cover that maintained temperature at above $00 \mathrm{C}$. The number of users for the treatment system is two, with a water consumption rate at around $70 \mathrm{~L}$ of water per person per day, the wastewater is pumped into the vermifilter every second or third day.

For the assessment of the raw and treated wastewater, samples were collected from the 


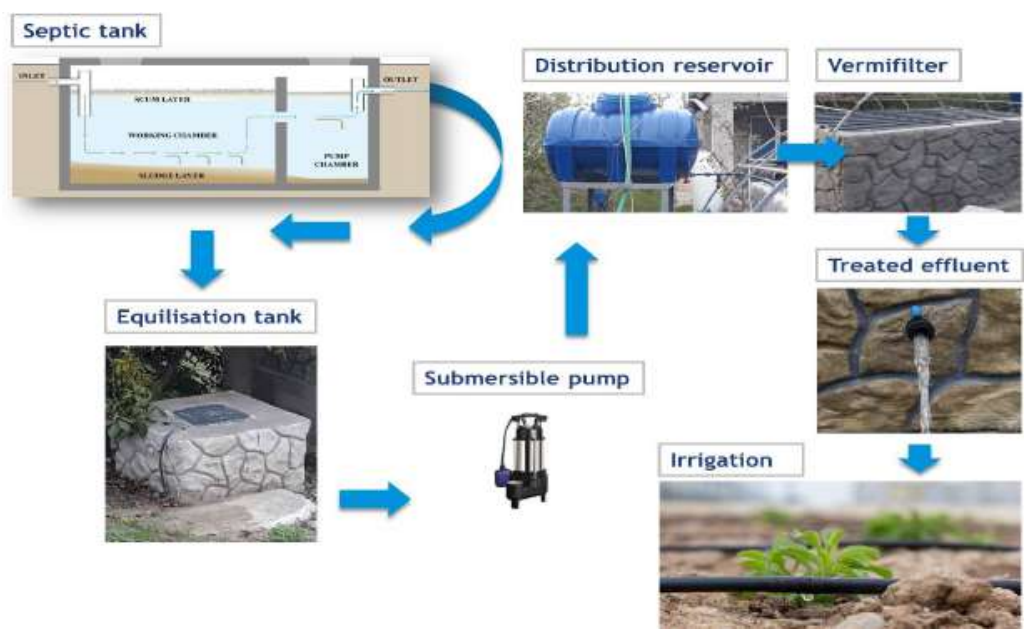

Figure 2. A schematic view of a demonstration vermifiltre built by WiSDOM association in a rural area of Moldova, at household level [3]

first chamber of the septic tank and from the effluent tap of vermifiltration unit. The values of permanganate chemical oxygen demand (CODMn) (allowing to potentially assess the level of degradation of easily degradable organic substances) and dichromate chemical oxygen demand (CODCr) (allowing to assess degradation of hardly degradable organic substances) were obtained by titrimetric methods, using automatic burettes Pellet and digital Solarus, after boiling and catalytic oxidation of the wastewater samples [5, 6]. The content of nutrients was determined by spectrophotometric methods [7-10] using the UV-VIS Specord 210 AnalyticJena spectrophotometer.

\section{Results and discussion}

As can be seen in Table 1, there was a considerable reduction of ammonia content (with 98,85 \%) (see also evidence in Figure 3), a moderate reduction of CODMn (easily degradable organic substances) - with 49,21\% CODCr (hardly degradable organic substances) - with $85,28 \%$. Considering the fact that the concentration of nitrite nitrogen and nitrate nitrogen was very low $-0,002 \mathrm{mg} / \mathrm{l}$, it can be assumed that the role of earthworms in ammonium cleavage was insignificant and the reduction of ammonium nitrogen was mainly due to its absorption on biochar. It can be assumed that at the time of sampling it was not sufficient time (at least few months) for the microorganisms, interacting symbiotically and synergistically with earthworms to be developed in the vermifilter bed, which would have allowed an efficient organic and ammonia transformations processes. Additional research shall be done after the community of microorganisms will be well developed. For an effective wastewater treatment, a particular attention shall also be paid to earthworm density - 15,000 specimens $/ \mathrm{m} 2$ also, the use for bedding and filter media also have effects on the establishment of microbial biofilms and the microbial community structure within the vermifilter and the treatment performance [11]. 
Table 1. Content of nutrients and chemical oxygen demand in raw wastewater and treated effluent

\begin{tabular}{|l|c|c|}
\hline & Untreated wastewater & Treated wastewater \\
\hline $\mathrm{NH}_{4}{ }^{+}-\mathrm{N}, \mathrm{mg} / 1$ & 14,60 & 0,17 \\
\hline $\mathrm{NO}_{2}-\mathrm{N}, \mathrm{mg} / \mathrm{l}$ & 0,002 & 0,002 \\
\hline $\mathrm{NO}_{3}{ }^{-}-\mathrm{N}, \mathrm{mg} / \mathrm{l}$ & 0,002 & 0,002 \\
\hline $\mathrm{PO}_{4}^{3-}-\mathrm{P}, \mathrm{mg} / \mathrm{l}$ & & 0,01 \\
\hline $\mathrm{COD}_{\mathrm{Mn}}, \mathrm{mgO}_{2} / 1$ & 39,00 & 9,29 \\
\hline $\mathrm{COD}_{\mathrm{Cr}}, \mathrm{mgO}_{2} / 1$ & 330,23 & 57,14 \\
\hline
\end{tabular}

For an efficient wastewater recycling, the vermifilter was connected to a greenhouse, where some vegetables and decorative plants are grown. At the moment, after 10 months of use, the following issues affected the functionality of the vermifilter:

1) Freezing of the wastewater in the vermifilter and the pipes during long cold periods (26 January-04 February), when the temperature during the day and night was fluctuating between -5 and $-8{ }^{\circ} \mathrm{C}$. The vermifilter could not be used for one week due to freezing of water in the pipes, also a fraction of the earthworms died. A good insulation is required of the greenhouse and the pipes in order to avoid such problems in the future.

2) Smell issue during the distribution of wastewater from the distribution reservoir onto the vermifilter. This was solved by adding activated lactic acid bacteria from kefir or yogurt starters, which are available in the supermarket. The cost of these starters in the Republic of Moldova is 60 lei and one box of 4 phials can be sufficient for 4-6 months, thus the costs are insignificant for the users of the vermifilter. At the moment, no complains from neighbors about the smell were received yet. However, it is necessary to further reduce the smell for the comfort of the users themselves.

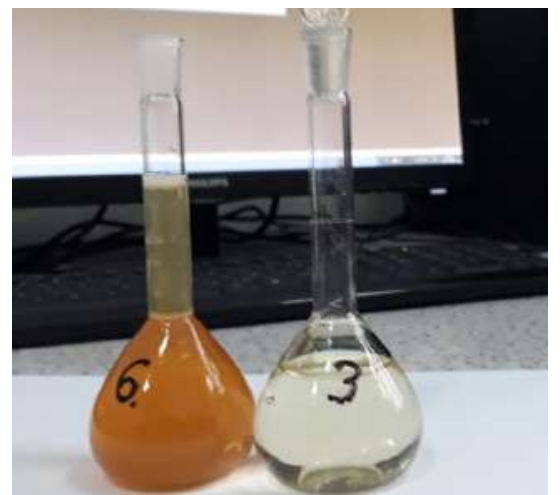

Figure 3. Representative color change for ammonia content in treated and untreated wastewater

Considering the first results from the use of vermifiltration systems for treatment of greywater (wastewater coming from the kitchen and laundry), such systems seems to be suitable to be applied at household level or even for some institutions, e.g. school or kindergarten, where 
the water consumption is not very high and thus the production of wastewater. The reason why vermifiltration can be implemented in rural areas is that this technology is environmentally friendly, as it allows reuse of treated wastewater in irrigation, it is relatively easy to manage and not capital-intensive [1]. This is particularly important in Moldova under the conditions of water stress during summer dry periods.

Acknowledgements. The research was carried out within BSB27 MONITOX project of JOP Black Sea Basin 2014-2020 and 17-EC/2020/SIDA project carried out by WiSDOM in cooperation with Ecotox Association.

\section{Bibliography}

1. Rajneesh Singh, Puspendu Bhunia, Rajesh R. Dash, A mechanistic review on vermifiltration of wastewater: Design, operation and performance, Journal of Environmental Management, Volume 197, 2017, Pages 656-672, ISSN 0301-4797, https://doi.org/10.1016/j.jenvman.2017.04.042.

2. Rajiv K. Sinha, Sunita Agarwal, Krunal Chauhan, Vinod Chandran, Brijal Kiranbhai Soni Vermiculture Technology: Reviving the Dreams of Sir Charles Darwin for Scientific Use of Earthworms in Sustainable Development ProgramsTechnology and Investment $>$ Vol.1 No.3, August 2010

3. Elena Zubcov, Nadejda Andreev, Nina Bagrin, Natalia Zubcov, Liubovi Lebedenco, Anastasia Ivanova. Ghid de gestionare durabilă a deșeurilor organice în scopul prevenirii poluării apelor. Chisinau, Ecotox, WiSDOM, 2021.

4. Iskreva D., Idigo J., Andreev N., Gyaurov A., Bilețchi L., Lebedenco L.,Zubcov E., Ivanova A., Bagrin N., Ungureanu G., Zubcov E., Ungureanu G., Zubcov N., Kozak T., Parafenco, O., Kiryian A., Mischchenko, Y. 2021 Training Pack on the main sources of pollution of rivers and the best available solutions for reducing river littering, Published by CRoCuS project.

5. COD by potassium permanganate ISO 8467:1993 Water quality - Determination of permanganate index. National version: SM SR EN ISO 8467:2006. Calitatea apei. Determinarea indicelui de permanganat.

6. COD by potassium dichromate ISO 6060:1989 Water quality- Determination of the chemical oxygen demand. National version: SM SR ISO 6060:2006. Calitatea apei. Determinarea consumului chimic de oxigen.

7. N-NH4+ ISO 7150-1:1984. Water quality - Determination of ammonium - Part 1: Manual spetrometric method. National version: SM SR ISO 7150-1:2005 Calitatea apei. Determinarea conţinutului de amoniu. Partea 1: Metoda spectrometrică manuală.

8. N-NO3- ISO 7890-3:1988 Water quality - Determination of nitrate - Part 3: Spectrometric method using sulfosalicylic acid. National version: SM SR ISO 7890-3:2006 Calitatea apei. Determinarea conținutului de azotaţi. Partea 3. Metodă spectrometrică cu acid sulfosalicilic.

9. N-NO2- (Alekin, 1973) spectrophotometric metod

10. ISO 6878:2004 Water quality - Spectrometric determination of phosphorus using ammonium molybdate. National version: SM SR EN ISO 6878:2011 Calitatea apei. Determinarea fosforului. Metoda spectrometrică cu molibdat de amoniu.

11. Sudipti Arora, Sakshi Saraswat, Vermifiltration as a natural, sustainable and green technology for environmental remediation: A new paradigm for wastewater treatment process, Current Research in Green and Sustainable Chemistry, Volume 4, 2021, 100061, https://doi.org/10.1016/j. crgsc.2021.100061. 